\title{
Sciendo
}

DOI: $10.2478 / \mathrm{aa}-2019-0007$

\section{The devil inside that won't be caged or fixed by words: Fluidity and ethics in Ian McGuire's The North Water}

Petr Chalupský

Petr Chalupský is Associate Professor at the Department of English Language and Literature, Faculty of Education, Charles University, where he teaches courses in English Literature, Literary Studies and Literary Theory. His research and publication activities focus on contemporary British fiction. He is the author of the monographs The Postmodern City of Dreadful Night: The Image of the City in the Works of Martin Amis and Ian McEwan (2009) and A Horror and a Beauty: The World of Peter Ackroyd's London Novels (2016).

\begin{abstract}
In Ian McGuire's novel The North Water (2016), Patrick Sumner, a young medical doctor recently dismissed from the British Army with his reputation and professional prospects in ruins, accepts a poorly paid position as a surgeon on a whaling ship in his attempt to flee from his past and his troubled conscience. However, contrary to his expectations, in the Arctic Circle he faces an ordeal far more demanding than anything he has hitherto endured in the form of the harpooner Henry Drax, a dangerous psychopath who is ready to abuse and murder anyone who is an obstacle to the satisfaction of his brutish physical needs. Confronted with violence and cruelty beyond understanding, within the fluid framework of the distorted ethical norms and values of the heterogeneous crew, the embittered Sumner is gradually forced to abandon his protective shell of resigned indifference and reassess the moral stances and responsibilities of a civilized person when faced with human wickedness. Though McGuire acknowledges primarily the inspiration of Herman Melville and Cormac McCarthy, this paper argues that in ethical terms the novel responds to Joseph Conrad's Lord Jim and Heart of Darkness, pushing the protagonist's relationship to the other to an extreme by making the other an embodiment of pure evil.
\end{abstract}

The North Water, a 2016 Man Booker Prize longlist nominee, is a historical novel written by Ian McGuire (b. 1964). Set in late 1850s England, the novel's plotline revolves around a whaling ship's expedition heading to the Arctic Circle. Interestingly, McGuire's path to this book was in fact a result of a coincidence, as originally he intended to write a biographical novel about his beloved Herman Melville, but after about a year he found himself unable to complete the project. However, while researching materials about $19^{\text {th }}$-century whaling he discovered a copy of the diary kept by Arthur Conan Doyle, who as an 18-year-old Edinburgh medical 
student spent a summer as a surgeon on a whaling ship. Although this diary does not contain anything unusual, the authorship of the renowned detective writer inspired him to create a murder story aboard a whaling vessel (Historia, 2017). Though completely different from his original plan, the idea gradually grew appealing to him. Yet he by no means wanted to make it a pastiche of Doyle's Holmes series or a conventional "whodunit" crime novel (Steger, 2017), and so he opted for a story which involves multiple crimes yet which by far transcends the generic limits of crime fiction. In order to produce an atmosphere of uncertainty, crisis and corruption in which various forms of transgression thrive and proliferate, McGuire chose to compose his story on the background of the declining Victorian whaling industry in Hull, a town near which he had grown up.

A writer of historical fiction revels precisely in those factual gaps - the unknown, obscure and undocumented aspects of the past - that trouble a historian, but which he/she is free to fill in by using his/her poetic licence. In this regard, Arctic whaling proved to be suitable material for McGuire as the recent historical literature dealing with this theme is relatively limited, and neither is there much physical evidence available, which left sufficient space for his imagination (Hyde, 2017). For the most part of his research, he had to rely on authentic written accounts from that time, especially journals kept by Arctic voyagers and surgeons on whaling ships, who were learned men with enough time to note down their experience (Hunt). And although neither of these records contains any truly sensational events that would be at least close to the atrocities McGuire portrays in his novel, but rather daily seafaring and medical routines, the peculiar and claustrophobic environment of the far-sailing ship occupied by a heterogeneous, haphazardly assembled crew served him as a perfectly convenient setting for his uncanny story of villainy and viciousness. By doing so, this paper argues, The North Water follows the tradition of fiction centered on a fallible, transgressive protagonist who, under extreme and volatile circumstances, balances on the blurred border between good and evil. The novel can thus be read as a compelling response to Conradian ethical queries, particularly regarding the relationship between "I" and the "other" which resonates with discourse concerning such ethical issues in the present day.

\section{(Inter)textual context}

As for the novel's (inter)textual context, McGuire acknowledges especially the influence of Herman Melville and Cormac McCarthy, which points to the text's reconciliation of the $19^{\text {th }}$ century and contemporary sensibilities. The inspiration of the former is inevitable given by the abovementioned background of its creation, but McGuire stresses that his goal was to write a 
maritime novel Melville could not and would not have written, which is the case both contentwise and in terms of the language and narration. He thus sees his novel as "a homage to Melville but also a kind of revision of Moby Dick" (RNZ, 2017). Regarding the latter, McGuire admires McCarthy's unique ability of switching between different kinds of language registers within one story (Steger, 2017) and admits that the elements of the thriller in The North Water owe much to McCarthy's influence (Hunt), namely that of Blood Meridian (1985). ${ }^{1}$ Moreover, other possible influences have been suggested by critics and reviewers (e.g. Evans, O'Donnell, Toibin, Rigsby), including that of the Victorian rogues' gallery cast, namely the character of Quilp in Charles Dickens's The Old Curiosity Shop (1841). In terms of the sea-faring canon, the maritime fictions of E.A. Poe and Jack London have been repeatedly mentioned, particularly London's The Sea Wolf (1904) with its crude language and the devilish figure of Wolf Larsen, the story's central villain, whose viciousness the sensitive and well-mannered protagonist Humphrey van Weyden is forced to oppose against his nature. A more recent source of inspiration in this regard may be Patrick O'Brian's Aubrey-Maturin series (1969-1999) of sea novels set in the early $19^{\text {th }}$ century during and shortly after the Napoleonic wars.

However, the concept of good and evil The North Water almost spontaneously calls to mind is that of Joseph Conrad, specifically in his Heart of Darkness (1899) and Lord Jim (1900), which has also been observed by some critics (e.g. Cartwright, Dunmore, Forbes). In the first place, McGuire's protagonist is haunted by twinges of conscience of his past moral failure and subsequent loss of honour, which have obstructed his professional career and made him a disgraced and embittered shadow of his former personality, similarly to Conrad's eponymous character in Lord Jim. Also, the novel contemplates the sometimes inscrutable otherness of another person and how one's ethical being when confronted with pathological unscrupulous wickedness can make one lonely and desolate, just as Marlow articulates: "It is when we try to grapple with another man's intimate need that we perceive how incomprehensible, wavering and misty are the beings that share with us the sight of the stars and the warmth of the sun. It is as if loneliness were a hard and absolute condition of existence" (Conrad, 1999, p. 105). Moreover, “just as Conrad will not offer his Lord Jim any easy redemption, and seems, in any case, more concerned with the texture of the prose and the novel form itself [...], so too McGuire seeks to use his tale of unredemption as a way to animate his own style and allow it to flourish" (Toibin, 2016), yet admittedly by different linguistic and stylistic means. Also, in terms of narration, though written in the third person, the actual story of The North Water unfolds in the vein of Conrad's recounting of Marlow's “inconclusive experiences" (Conrad, 1983, p. 10), rather than in that of the Victorian novel: not only does it 
lack the conventional satisfactory closure that would integrate the protagonist into society, but also it retains its moral openness through refraining from any explicit ethical judgement neither from the protagonist nor as well as from the narrator. And, as in Heart of Darkness, the novel works forcefully on the level of moral (self-)scrutiny to which the protagonist is compelled through an encounter with an evil beyond his current experience.

\section{Ethics and fiction}

Ethics represents a specific kind of knowledge, with its own distinct properties and constitutive elements. As acquiring such knowledge is a convoluted process which involves one's upbringing, social and cultural environment, as well as temperament, it is much less tangible to define and grasp than other forms of knowledge, such as the pragmatic or scientific. Basically, ethical knowledge is non-empirical, non-causal and non-coercive. Ethical belief cannot be explained by ethical truth, guided by some external ethical reality, or derived from experience by means of inductive inference. Therefore, our moral judgements may be "elicited by experience, and indeed they must be", but they "cannot be proved by experience" (Russell, p. 36). Also, moral properties do not produce causal effect. Unlike physical facts and events, they do not cause beliefs about them, they can only be chosen to apply, which is the sole way "in which they can influence the course of events" - "if they are represented by some subject" (McGinn, 2003, p. 26). Moreover, ethical facts lack coercive potential; they cannot correct one's mistakes or punish one for violating moral principles. They are recommendations that tell us what we ought to do, not commands or laws backed by a system of penalties and rewards or some other kind of authority that would enforce their observance. Consequently, as ethical truths are evaluative in nature, they lack pragmatic justification and thus must be pursued for their own sake, which makes them irrelevant to desire satisfaction (McGinn, 2003, pp. 51-55) and accounts for the disunity in moral choices of otherwise socially and culturally homogeneous individuals.

The quality of a society's culture, climate and value system influence the morality of the community by publicly promoting goodness of character. Moral education does not consist of only straightforward and illustrative instruction but also involves a great number of indirect means of fostering one's ethical principles. This suggests that acquisition of a complex ethical system cannot merely be a result of external forces, of our being exposed to a certain sociocultural environment, but must have its basis in human nature. Noam Chomsky notes that while growing up one can acquire fundamental moral norms and principles of judgement, but these 
are not supported by sufficient empirical evidence. The environment is "far too impoverished and indeterminate to provide this system to the child, in its full richness and applicability", which is why in certain situations these judgements are found "inconsistent with the person's own internalized principles" (1988, pp. 152-153). A parallel may be drawn between ethical knowledge and linguistic knowledge, our mastery of language, as the norms of moral conduct are similarly rooted in the human mind as those of grammar. In spite of language dissimilarities within communities as well as across different cultures, there are common linguistic universals which make some elemental understanding and communication possible. Similarly, there are some shared common ethical principles that result in a "huge amount of basic agreement between cultures and epochs about simple morality" (McGinn, 2003, p. 48). Yet just as certain individuals of the same socio-cultural community are more at ease with language - more fluent, consistent, eloquent, playful - there are also those more forcefully inclined to making ethical choices of altruism, charity and compassion, which, in both cases, they owe to an extent to some innate human faculty.

Morality operates on personal and social levels. Human beings are driven by conscious and unconscious desires and strivings, yet this pursuit of urges and goals should always reflect and respect other people's needs and interests. Ethics tells us how to "reconcile and adjust these twin forces, the personal and the social" (Pojman, 2000, p. 2). Self-conscious reflection exercised by reason is more likely to suppress the will towards self-serving and violent acts through submitting to collective ethical commitments. "As a general rule, any movement that encourages greater emotional attachment to others strongly militates against the loom of destruction [...] When people are governed by empathy and conscience, reason is marshalled in service of justice and the pursuit of the ethical” (Mills, 2016, p. 17). In other words, a positive relationship to another person is the core of our morality. Therefore, in a dysfunctional society where interpersonal ties are torn and people feel continuously abused and subjected to injustice a universal ethical principle and the belief in it are shattered and questioned. People who continually experience uneasiness and deprivation concerning their physical, material, social and emotional needs tend to withdraw into themselves and egoistically turn to seeking ways in which their most basic desires and urges might be satisfied, which often entails inconsiderateness, indifference and resorting to violence.

This behaviour, however, cannot be regarded as evil in the proper sense as it is subsumed within psychological egoism, which says that people in principle pursue their own interests. Ethical egoism, on the other hand, stresses that promoting one's own interest is one's right and duty. While the first stems from self-interest, which is "the legitimate concern we have to satisfy 
our wants and interests" and in a limited form is congruent with "reciprocal altruism", the latter is propelled by selfishness, which means "enhancing [one's] own welfare even to the detriment of others" (Pojman, 2000, p. 540), which makes it the root of evil. Another difference is in motivation: in the first case it is primarily that of avoiding pain, deprivation and discomfort, the latter case is prompted by unscrupulous drive towards pleasure, and it is this uncontrollable hedonistic impulse that constitutes an evil disposition.

Each person has some degree of egocentrism and self-love in their character, as well as a certain degree of goodness and meanness in proportion. Growing out of this egocentricity is not only a necessary condition for becoming mature, but also an inner transformation that enables one to move towards goodness and freedom as such a person ceases to be a slave of one's immediate needs and desires and can increasingly concern oneself with the outside world. This maturity, however, is an ideal state towards which one moves but can hardly be reached fully. At the opposite, immature, end, moral principles are subordinated to psychological needs, and in extreme cases, "where a person's egocentric needs are sovereign, the person is alienated from morality altogether. It is then that he is ripe to fall into evil. All it takes is for him to give in to this temptation" (Dilman, 2005, p. 128). Yet, this does not mean that submitting to one's psychology is excusable (Dilman, 2005, p. 155). And so although they are both moral concepts, there is a fundamental asymmetry between good and evil. Evil is explicable in terms of an individual person's determining psychology: one can fall into it by simply doing nothing, by surrendering to the "moral gravity" of one's innate needs and desires towards moral indifference. On the contrary, goodness has no such explanation since it must come from a person, one does not fall into it but rises against the moral gravity's pull (Weil qt. in Dilman, 2005, p. 131), and therefore it must be learned and acquired, which requires considerable inner strength and self-denial.

What follows is the fact that moral learning is a long-term, incessant process in which one's active participation must be invested. As doing good cannot be imposed by one's psychology, a person must be willing to make such a demanding commitment since it involves giving oneself to something beyond, an act which presupposes surpassing one's egocentric drives. The evil motive, by contrast, is essentially primitive and straightforward, and as such always precedes rational reasoning, though perpetrators of evil often try to rationalize their acts ex post so as to make them look more justifiable. We can distinguish between instrumental evil and pure evil. In instrumental evil the inflicted malice and pain are not the actual goal of the act, but are seen as necessary means of achieving something else. Pure evil, then, means deriving pleasure from others' pain (and pain from others' pleasure) - it is inflicting harm and 
suffering for their own sake. Pure evil can take a passive form: a person need not be the very agent of an evil act but its spectator who, however, must relish such a spectacle. "What matters is the state that pain produces in him, not necessarily his agency in producing it" (McGinn, 2003, p. 66). Indifference to someone else's pain, on the other hand, though a moral failure that falls into the general understanding of evil, cannot be regarded as pure evil as it does not meet the criterion that this pain must enhance the evil person's contentment.

In literature, and fiction in particular, ethical preoccupations intersect with aesthetic and narrative aspects through the ethical dimension ascribed to fictional characters and their actions. As McGinn notes, "the human ethical sensibility works best when dealing with particular persons in specific contexts; abstract generalities are not the natural modus operandi of the moral sense" (2003, p. 3). This is precisely what works of fiction can do: to combine the particular with the universal, to impart specific characters in specific situations with general moral principles, in an imaginative and ingenious manner so that readers find these dilemmas and conflicts intelligible, relatable and appealing at the same time. Naturally, more voluminous genres, such as the novel, are better suited in this regard as they offer enough space for the author to construct and develop the story carefully so as to render the ethical issues plausibly and convincingly. Therefore, "in their own particular manner, novels perform an ethical work, or can be made to, and it is worth trying to enable that work to take place" (Gibson, 2001, p. 1). This ethical work operates in two ways: the presence of the moral framework gives greater significance to the particular material which, in return, exemplifies and substantiates more general questions which might otherwise escape the reader's attention.

In order to endow a story with an ethical dimension, a set of necessary constituents must be imported into it. Paramount among them are the two contesting principles of good and evil rendered through characters embodying respective qualities and character traits. As the majority of the population is made up of people who do observe essential moral principles, though with idiosyncratic intensity and consistency, those individuals who infringe them assume a crucial role in the plot. These villainous characters may be of different types depending on the motivation behind their acts and the degree of their propensity for pathological behaviour. Based on the psychological Theories of Causal Attribution, Enrique Cámara Arenas proposes a model in which a villain's actions may be perceived from three causalities: first, as the direct response to a given stimulus that justifies it; second, as a way of acting which is influenced by a set of circumstances; and third, as a manifestation of the villain's personal dispositions (2011, p. 18). While the first two are determined by external factors, the third results from an internal cause. In the first two cases we thus cannot strictly speak of purely evil individuals as such 
classification requires the presence of some inner wickedness. This is further supported by the principle of general consensus - high or low - about the nature of a person's acts. "High consensus implies the notion that most people would react in a similar way when faced with the same factors. If a villain's actions are understood as high in consensus, his or her villainy is dramatically qualified" (Arenas, 2011, p. 19). Again, higher consensus is likely to occur in the first two causalities where external factors come into play, while the third causality would result in rather lower consensus as people have difficulties with identifying with someone's internal evil disposition.

For a truly grand moral conflict a story needs at least one character whose behaviour cannot be fully explained or justified by external circumstances, that is one of the third causality or its combination with the other two options, a character with low consensus with the majority of both other characters and readers. The presence or appearance of such a personality, who ignores or deliberately violates underlying moral norms without any sign of compunction, interferes with other people's wellbeing and disturbs the matrix and hierarchy of standard personal relationships. This forces other people to get out of the comfortable shell of abiding by conventions and norms of appropriate conduct and polite manners as they prove ineffective in dealing with this kind of otherness. The ethical framework of the story thus rests in a quandary in which a character, or characters, is challenged by the need to assume responsibility for a larger community by confronting an unprecedented evil. This, however, necessitates taking one-time pragmatic measures well outside the range of what he/she considers as ethically acceptable, with which he/she thus feels highly uneasy, disconcerted or even disgusted, which may hinder him/her from a timely resolution of the dilemma.

\section{Ethics and evil in The North Water}

If on the aesthetic level historical fiction makes decisions about the specific artistic means through which it (re)encounters and (re)presents historical reality, the ethical level entails all the moral, social, psychological, cultural, intellectual and political meanings and implications resulting from this aesthetic choice. The complexity of the latter presupposes approaching $19^{\text {th }}$ century people as ethical subjects, that is people who are "entitled to the same consideration for their actions and perspectives as we would hope to receive for our own" (Andress, 1998, p. 240). Being able to better define and comprehend our vantage point by viewing the past through the prism of the present is one of the effects of historical fiction's ability to interconnect the imaginative with the ethical, also, as Peter Mandler observes, thanks to the fact that historical 
distance allows us to tackle troubling queries with some of the pressure and urgency of the present-day discourse removed:

One of the purposes of historical time travel is to transport our modern selves into alien situations which allow us to highlight by contrast our own values and assumptions. Sometimes it is easier to examine complex ethical questions honestly and openly in an historical rather than in contemporary setting, the distancing involved in taking out some of the heat of the moment without disengaging entirely contemporary values and attitudes. (2002, p. 147)

McGuire voices a similar opinion when he claims that "historical novels usually tell us as much about the period in which they are written as they do about the period in which they are set" (Historia, 2017), and this is nowhere else more perceptible than in the domain of ethics. He admits that the actual creative process is in the first place determined by the need to produce a narrative which would be gripping, coherent and compact content-wise as well as technically, rather than guided by some explicit moral purpose. That is why while writing he is interested in violence and perversity as powerful constituents of the story's dramatic composition if used properly (Hunt). Yet he is also convinced that good literature should always express an "ethical impulse" and thus offer itself as an "act of hope", through which "the writer is pushing back against the forces of confusion and disorder" (Hyde, 2017), thus addressing sentiments felt and experienced by both characters and readers.

Although The North Water features several potentially traumatic events and experiences, it does not fall into the category of trauma fiction as it does not give expression to repressed feelings and emotions through "highly troped, figurative language" (Onega, del Río, Escudero-Alías, 2017, p. 7). On the contrary, when it comes to their inner life the characters are notably reticent and uncommunicative, resorting to curt comments and plentiful swearing, and the narrative turns to inventive figurativeness when portraying external reality - for the descriptions of mostly violent acts and the imminent might and beauty of natural world. The novel is much more concerned with action and vivid detail which, as Toibin (2016) notes, makes its central rivals' presence forceful in spite of their lack of greater psychological complexity. Rather than for introspection, by exposing his characters to diverse manifestations of monstrosity, violence and depravity, the story prompts the readers to perceive these individuals as potential other sides of their self. This "self-as-other" approach is not limited only to victims, "but also includes primary and secondary witnesses as well as bystanders, 
collaborators, and perpetrators implicated in historical violence and atrocity" (Kohlke \& Gutleben, 2010, p. 14).

It is important to point out that with regard to ethical concerns The North Water is a remarkably complex and multi-layered text as the other to which its protagonists have to relate and respond assumes at least three significant forms. Apart from the otherness of other people, mainly Englishmen like the whalers, Baxter and the priest, there is the magnificent yet unyielding natural world of the Arctic whose powerful and untameable permanence and serenity make for a stark contrast to the fickleness and impotence of the whalers drowning in trifle, malice and violence. McGuire himself stresses that the story is as much about the relationships between its characters as it is about the relationship between the human and the natural world, both representing a version of animality, though the latter being a far more appealing one (Historia, 2017). The novel thus invites scrutiny of the character and implications of this relationship from relevant critical perspectives, namely that of geopoetics and ecocriticism. The third kind of otherness in the novel is ethnical in the form of the Inuit, and it touches upon the peculiarities of the relationship between these natives and the Europeans, which is why it is also open to postcolonial examination. However, for the purposes of the present analysis, the ethical dimension of the first type of relationship - of a person to another person - will be taken as the pivotal point of departure.

Delving into the extremities of human nature and experience enables the author to conceive and ponder various forms of otherness on both ends of the committed injustice. This access to and concern for the other adverts to Emmanuel Levinas's understanding of ethics as an "ethics of alterity", in or through which the self is "enlarged and enriched by the other and transcends its own egoistic limits" (Kohlke \& Gutleben, 2010, p. 20). For Levinas, it is a concrete and personal relation to another being, via an encounter with the face of the other, which makes the self realize the impossibility of mastering the other and commands it to recognize its moral responsibility that rests in responding to the other through a generous act of giving. This response is principally carried out in language, by means of communication, that is by speaking "to" the other, not "of" or "about" the other (Blanchot, 1986, p. 45). "Thus the encounter with the face and through language has an absolute ethical priority over cognition and representation. For to speak in response to the other is always, in the first instance, to refuse to reduce the other to terms, to greet him or her in his or her difference" (Gibson, 1999, p. 64), to acknowledge the priority of the other and refrain from making judgements and conclusive truths. McGuire's novel, however, challenges this ethical imperative by making the central form of otherness verge on the realm of the unspeakable. 


\section{Conradian moral framework}

In ethical terms, The North Water draws distinctly on the fictional world of Joseph Conrad. On the framework level, it can be seen as analogous to Lord Jim in that it presents a fallible central protagonist who has lost his professional honour and, publicly disgraced, has hit rock bottom. Being a well-mannered, reasonably ambitious person, this loss of future career opportunities together with the feeling of embarrassment at his moral failure and bitterness for having been betrayed by his superiors make him a resigned, withdrawn, evasive man whose life has been turned into a series of ineffective attempts to escape himself and his guilty conscience. Like Conrad's Jim's inexcusable abandoning of a ship in distress, Patrick Sumner's voluntary involvement in a shameful act of greed during the 1857 Siege of Delhi where he was serving as an army surgeon, due to which he left his field hospital while on duty and, unlike his less fortunate dead colleagues, returned there too late and with a wounded leg, resulting in his being court-martialled and subsequent dismissal from the army with practically no chance to resume his medical career in England. Brought down and depressed by his futile efforts to find a medical institution where the blot on his reputation would not be found disqualifying, Sumner takes to opium so as to at least temporarily alleviate his distressed consciousness. Almost penniless and with bleak prospects regarding finding a satisfactory job, he accepts the ill-paid post of surgeon on a whaling ship which is about to set off for a long voyage to the Arctic. For him, an Arctic whaler is "a place where few questions will be asked, where his misdeeds may go undiscovered" (O’Donnell, 2016), where he can become nameless and past-less. He hopes that the months on the sea will help him forget the past, rest his mind, collect his thoughts, summon up his wits and make plans for restarting his life.

As far as the protagonist's actual moral dilemma is concerned, however, McGuire's novel to a considerable extent resonates with Heart of Darkness. Conrad places Marlow far away from the civilized world, into the extreme conditions of the heart of the African continent, where as a captain of an ivory trading company's steamboat he is to search for Mr Kurtz, a once promising and successful agent, with whom the company has lost contact. It is this encounter with and exposure to utmost otherness and savagery, in utter solitude and without the comfort of the butcher, the policemen and the kind neighbour, these "little things that make all the great difference" (Conrad, 1983, p. 85), that truly test one's character. Under such circumstances, as Marlow notes, mere “[f]ine sentiments" and "[p]rinciples won't do" as one must rely on one's "inborn strength" (Conrad, 1983, p. 69). Kurtz, who lacks this strength, then falls prey to his lusts and appetites, whose whisper "echoe[s] loudly within him" and proves to be too 
“irresistibly fascinating” (Conrad, 1983, p. 97) for him. Conrad thus "suggests and dramatizes evil as an active energy (Kurtz and his unspeakable lusts) but defines evil as vacancy" (Guerard qt. in Paulson, 2007, p. 215), the absence of one's innate capacity for restraint and self-denial which would allow one to resist surrendering to one's immediate desires.

The ethical work of Heart of Darkness is built on the confrontation between Kurtz's and Marlow's attitude towards the other. The former, though appearing humanistic at first, turns out to be driven by the will to totalize, towards domination which manifests itself especially through the excessive use of rhetorical discourse. Kurtz's power of monological articulacy, “of burning noble words" (Conrad, 1983, p. 87), is in fact a form of violence which "refuses to listen, refuses exchange, assimilation, hybridization, self-reflexivity" and therefore "permits no encounter with the other" (Gibson, 2001, pp. 59-60). As a result, his "magnificent eloquence" makes his audience impressed, astonished or even dismayed but little affected since its form outweighs the content. Marlowe's approach, on the other hand, contests and undermines Kurtz's urge towards ontological mastery by its will to dialogical (self-)scrutiny and (self-)reflexivity which opens itself to ethical relation to the other. His discourse "might be said to open up an ethical space in which alterity is registered precisely as it persistently and forever exceeds cognition and indicates the limits of ontology" (Gibson, 2001, p. 63). This openness allows him to interpret Kurtz's dying words as "a moral victory" (Conrad, 1983, p. 113) and remain loyal to him in his encounter with Kurtz's fiancé during which he abandons his conclusive truth for the sake of the priority of the face of the other. In Levinasian terms, the white lie Marlow tells the bereaved young woman is intrinsically ethical as he "gives up his knowledge in favour of the other's need, and thus resorts to a very different conception of ethics and justice [...] that has hitherto dominated the novel" (Gibson, 2001, p. 65). Rather than faint-hearted evasiveness, it is a sign of acknowledgement and affirmation of moral responsibility through the selfless act of giving.

\section{Encountering the evil other}

Since the beginning of the genre, there have been novels about the sea - from Defoe, via Cooper, Melville, Conrad, London and Forester, up to contemporary writers such as Patrick O'Brian, Sebastian Junger, R.E. McDermott and Ian McGuire. The main reason behind writers' and readers' fascination with the sea is its vast difference from what we experience for most of our lives on land: it is never still, almost endless, hostile to move in, inexorable in its immensity and force, impossible to tame and control, difficult to anticipate. It is an environment in which, within a blink of an eye, human beings become helpless against the relentless might of nature. 
Moreover, it offers spectacular sceneries that cannot be found anywhere else, which even more stirs the authors' imagination. In the best maritime fiction, the sea is neither mere backdrop nor mere destructive force, but "a canvas of seductive blankness, a surface from which the clutter of civilised existence has been scoured. Against such emptiness, the dramatic force of a narrative is magnified, lending heroic proportions to its struggles" (O'Donnell, 2016). This is also the case of McGuire's novel which uses the topos of a seafaring vessel to construct a thrilling and uncompromising adventure story while, at the same time, providing a lucid yet stern vision of human mortality.

A ship on a long sea voyage is a particular environment in itself: a relatively small group of randomly assembled men who often do not know one another becomes an isolated community in the limited space of the vessel. This unavoidable physical proximity brings about a peculiar kind of intimacy among these half-strangers. Moreover, most of the crew are hired volunteers - seamen, fishermen, harpooners, workmen - that is hard, working-class men with little education and manners, motivated chiefly by the prospective earnings or, in the worst case, driven by their dubious pasts. These violent or criminal-minded individuals believe that the distance from the mainland created by the sea makes them safe from, or even free from, the laws and justice of civilized society. And so, despite the given hierarchy of rank and post, such a social milieu is by definition volatile, capricious and erratic, which makes the personalities of the senior members of this hierarchy - the captain and the first mate - crucial in keeping it a functional whole. In this regard, the novel's ship, called The Volunteer, is doomed from the very outset as doubtful and cryptic motives, secrets and histories surround its expedition. Baxter, the owner of The Volunteer, aware of the approaching end of the English whaling industry plans to convert the soon useless vessel into money through a complicated insurance fraud, in which a shipwreck would be caused intentionally near a Canadian Arctic shore and the crew would return home on another ship, The Hastings, "luckily" anchoring in the neighbouring bay. Whaling is thus reduced to a mere pretext for a much more dangerous and shadowy enterprise. For this conspiracy Baxter needs a captain willing to plot such an accident, which sends Brownlee into his arms. Brownlee was once a respectable whaling captain and would still rather pursue this career, but as his reputation is in ruins due to his previous disastrous voyage with The Percival, during which most of the crew died or were seriously injured, he has no other choice than to accept Baxter's offer if he wishes to captain a ship again.

McGuire makes Brownlee a pitiable character who refuses to admit that whaling is in decline, foolishly believing that the whales are hiding somewhere high above the Arctic Circle. As a captain, he has no say in choosing the crew members, including the first mate, as Baxter 
does it all for him, taking character disposition rather than skills and renown as decisive criterion for such selection. On top of this, he ironically prides himself on being "a fair judge of human character" (McGuire, 2016, p. 13), only to fatally misjudge the crew members' characters in critical situations, that of Henry Drax in particular. And so even without Drax, and all the more with him on board, with the captain a deluded fraudster, the first mate an opportunist bully and the second mate an ambitious and condescending egoist, the ship turns easily into a morally deplete space. Isolated on the north water, surrounded by the indifferent and merciless vastness of the Arctic landscape and exposed to life-threats emanating from both the natural world and other shipmates, these plain and uncomplicated men who "believe in act and consequence, capture and reward, in the simple geometry of cause and effect" (McGuire, 2016, p. 25) soon reduce their daily existence to avoiding discomfort and gratification of basic instincts, needs and desires. This self-protective and self-serving egoism together with the distorted and subdued social and emotional awareness of the heterogeneous crew result in the fluidity of ethical norms and values on The Volunteer, which makes the vessel a breeding ground for multifarious vices, from drink and brawl to sodomy and murder. Due to this atmosphere of apathetic or calculated disinterest in the essential norms of acceptable social conduct the embittered Sumner is gradually forced to abandon his protective shell of resigned and laudanum-induced torpor and reassess the moral stances and responsibilities of a civilized person when faced with ruthless wickedness.

The driving catalyst of Sumner's moral awakening is the sinister presence of Henry Drax. As a blend of heavy-drinking psychopath and sociopath without a trace of conscience, Drax is the embodiment of the purest form of evil, a monstrosity in human shape. There is nothing instrumental in what he does, he is not motivated by ambition to gain something or to hurt someone specific, he acts impulsively and compulsively, without any forethought. He does not plan his acts in advance, neither does he foresee nor ponder their consequences, he takes things as they come, each of them "separate and complete in itself" and none of them "prior or superior to the rest" (McGuire, 2016, pp. 139-140). He responds instantly to those impulses that disturb his immediate feeling of contentment - his bodily urges and desires as well as everything and everybody who may stand in his way towards their complete satisfaction. His is a perverted kind of animality, living only in the present, slaving to his appetites, not recognizing any obstacles in what he feels he needs to do, ready to resort to any means including violence and murder. When he feels lust during the voyage, he rapes a cabin boy; when the cabin boy resists being raped again he strangles him; when Sumner and Brownlee prove him guilty of this murder, his natural reaction is to kill them too. The identity of his victims is 
irrelevant to him, and he does not hesitate to slaughter two sleeping Inuit to get hold of their sledge and dog team to flee his captivity. Narration does not enter his mind very often as the repetitious linearity of his cause-effect psychology does not require it. "I do as I must. Int a great deal of cogitation involved" [...] "I don't intend too much. I'm a doer not a thinker, me, I follow my inclination" (McGuire, 2016, pp. 185, 191), he tells it straight to Sumner, revealing the brutal regularity that drives his wilful acts.

Sumner is an innately decent person with some rare human qualities, and so although his moral instincts have been somewhat numbed by guilt, self-reproach and opium addiction, he is not able to keep himself shut away in unconcerned apathy forever and is eventually roused from his obliviousness by the horrific crime and the fact that the alleged suspect may actually be innocent. Faced with the plain facts and evidence proving that the real murderer is still moving freely on the ship, he decides to uncover the truth. Yet he soon finds out that to discover and convict the culprit is just the first and relatively simple step, as the subsequent confrontation with the personality of Henry Drax proves to be far more demanding and exhausting. During his conversations with Drax, Sumner realizes that common decency and morality are futile and powerless against the fierce harpooner's mindset. Drux may be vulgar and uneducated, but he is not unintelligent and his reasoning from the position of extreme relativism of "a sort of berserk existentialist" (Steger, 2017) possesses a perverted logic impossible to defeat with rational argument.

Though deficient in articulacy, Drax's discourse, and worldview, like Kurtz's, is monological and totalizing, one that does not acknowledge a dissenting perspective, one unable to listen or modify, one governed by the will to conquer and dominate: the world is here for us only to grab as much of it for ourselves as we can before someone else does it - first come first served, take it or leave it. His premise that all people are alike in pursuing what suits and satisfies them best, but only give these things different names, like truth or morality; that enforcing law and justice is just another way in which a certain group of people are following their own inclinations and preferences which satisfies their egos by making them look more fair and smart than the rest; that good and evil are just words which can be used arbitrarily for different kinds of reality as one needs and wishes, since "[p]igs grunt, ducks quack and men tell lies: that is how it generally goes" (McGuire, 2016, p. 142); and that there is therefore no foundation for taking one's opinion as better or more correct than another's, leave Sumner lost for words and nauseous: "Talking to Drax is like shouting into the blackness and expecting the blackness to answer back in kind" (McGuire, 2016, p. 192). Drax's conviction that language is merely an instrument for utilitarian twisting and representing reality makes him immune from 
Sumner's discourse which he takes as a haughty attempt by the surgeon to demonstrate his supposed moral superiority.

As the story progresses, Sumner's sense of ethics and justice suffers one blow after another. Not only do conversations with Drax depress him, he is also worried by the increasing demoralization of the crew after Brownlee dies by Drax's hand. This only intensifies after the feigned shipwreck, and which is completed when the crew, to their horror, find out that The Hastings, the ship which is supposed to take them home, has sunk and they are destined to survive the inhospitable winter in the Arctic on their own. As misfortunes pile up, the desperate and frustrated shipmates turn to impassivity and superstition, concerned only with themselves and their fates, losing interest even in the manacled rapist and murderer Drax. Observing all that and realizing his helplessness in the face of such resignation, Sumner once again withdraws into himself and his bitter moral scepticism. The only person with whom he can share his feelings is Otto, the German harpooner and an adherent of Swedenborg's teaching who believes in the prophetic and visionary power of dreams. In Otto's view, as people are creatures of the Lord, they possess innate goodness, evil is turning away from this goodness and the only devil is to be found inside ourselves (McGuire, 2016, p. 241). Also, the material world we perceive through our senses is not the whole truth as it is not the corporal body but the spirit which truly lives, and which can only be fully grasped by means other than rational cognition, like imagination, visions and dreams. Therefore, language proves inadequate to express the whole truth as the most important questions cannot be answered with words, which is why grown up people should give them up (McGuire, 2016, p. 132). Based on his dreams, Otto predicts that all the crew will die save for Sumner who will survive "swallowed up by a bear" (McGuire, 2016, p. 172), which is exactly what happens later.

Sumner likes Otto for his thoughtfulness and kindness, but he cannot accept the harpooner's metaphysical ideas. He insists that thoughts come from us and our experience, not from God, that words are all we have and make us human, that good rather seems to be the absence of evil and that that miracles and great good do not occur, that Drax is a devilish monster rather than a tormented human spirit, and that dreams are detached from and unindicative of reality. Ironically, McGuire sees Sumner's persuasions contested by his own experience: he dreams that The Hastings is sunk before it happens, and is lost for words when trying to describe Drax's character. At this moment, Otto again reminds him that certain phenomena are beyond language and thus no such word exists, that a "fellow like him won't be caged in or fixed by words" (McGuire, 2016, p. 244), and can only be approached and accounted for by faith. Although Sumner comes to understand that certain individuals and 
events may be beyond experience and thus beyond standard and conventional categories of the acceptable and explicable, he does not know yet how his moral awareness should respond to them appropriately and Otto's meek faith does not provide him with a satisfactory answer. His disillusionment and frustration with the behaviour of the crew throw him into repeated resignation towards the outside world, and not even the fact that he miraculously survives when on the brink of death and later experiences unselfish goodness from the priest and the Inuit tribe makes him abandon this position, from which he strictly refuses the priest's request that he should "act as a good example of the civilised virtues" (McGuire, 2016, p. 276) for the natives. Interestingly, it is a minor incident from the point of view of the plotline that eventually arouses Sumner from the illusory comfort of this indifference. When the Inuit hunters find him unconscious but alive in the viscera of a killed polar bear, they take him for a spirit guide who can bring luck to their catch and so they ask him to accompany them while hunting seals. As a reward for his "help", one of the hunters sends one of his wives, Punnie, to give herself to him at night. Surprised at first, Sumner accepts this "gift" yet only on the reserved, impersonal level of his temporary social and moral solipsism. He takes it as mere physical act with "no greater meaning, no further implications", all he feels is a "purifying surge of inner blankness", taking part in a mutually salutary exchange whose benefit "he needs and wants to be nothing else" (McGuire, 2016, p. 282). This repeats each night - she presses her behind against his groin, in silence and darkness, without looking at each other. The last night after the coupling, however, Punnie turns to Sumner with a smile to say goodbye to him in her broken English. It is at this moment, looking into Punnie's eager and curious face, that he realizes the presence of another human being and feels ashamed, though not yet for his behaviour but for the fact that it "has been revealed to the world" (McGuire, 2016, p. 282) in its nakedness. It is only a few days later when, after another encounter with the face of the other, this time of Anna, the priest's Inuit maid, that he consents to stepping out of his comfort zone of moral irresponsibility and carry out a risky operation he has only read about so as to save the priest's life, an act he does entirely for the sake of another person and which brings his atrophied ethical sense back to life.

When he gets back to Hull, Sumner's feelings are similar to those of Marlow in Brussels - like Marlow's irritation at what he sees as a superficial, materialistic and pretentious life in the "sepulchral city", offensive to him "like the outrageous flauntings of folly in the face of a danger it is unable to comprehend" (Conrad, 1983, pp. 113-114), Sumner considers himself transformed by the extremity of his experience and perceives orderly civilized existence as "an aberration, a sleight of hand [...] an elaborate pantomime, a sham" (McGuire, 2016, p. 295). Having learnt what human beings are capable of if given a chance, he cannot help but look 
down on and sneer at such pretence. Yet although, like Marlow, he has "no particular desire to enlighten" (Conrad, 1983, p. 114) his fellow citizens, he feels moral responsibility to set certain things right and have justice done, which is why he decides to look up Baxter to confront him with the fact that he knows about the fraud behind The Volunteer's alleged shipwreck. Baxter embodies a different kind of menace to Drax: he is an instrumental evil, one who intentionally uses and abuses others to his own ends, one who does not react impulsively but schemes and intrigues. Sumner gradually understands that while Drax must be physically overpowered to get rid of his imminence, Baxter needs to be outwitted and tricked. In the end, getting over the sly and calculating Baxter thus proves to be a more demanding task than disposing of the straightforward alcoholic Drax. The final encounter with Baxter turns into a true ordeal for Sumner as using a combination of cunning ingratiation, wicked threats and generous payoff, Baxter almost beguiles him into resigning from his principles. Baxter's persuasive eloquence and financial offer throw him back into a seemingly enticing moral fluidity of volatile, pliable and thus easily violable rules and norms, evoking a world that is "unhinged, free-floating" (McGuire, 2016, p. 318), in which utmost relativism commands one to place succumbing to one's egoistic desires above the general law and welfare. This time, however, Sumner resists and does not repeat the same mistake as in Delhi, realizing that he must not play Baxter's game but set his own rules in order to get the situation under his control.

Sumner's moral victory is thus of a somewhat different nature to Marlow's. Marlow does not really find himself in an extreme situation of being confronted with human viciousness but rather becomes an observer in a cautionary tale of how progressing egoism and narcissism can turn into pure evil. His moral dilemma is thus that of an internal struggle with himself: at first in the Congo when summoning up his inner strength to restrain the "call of the wild", resign from his principles of decency and give himself to unbounded savagery; and later, during his meeting with Kurtz's fiancée, when forsaking his knowledge and experience to the benefit of another person. Sumner's struggle, on the other hand, is crucially determined by the presence of an external evil in the form of Drax and, later, Baxter. The landscape of the Arctic plays a different role to the African jungle ${ }^{2}$ - practically unpeopled, with its sinister frosty serenity it has a taming and humbling effect on the seamen rather than inviting them to confident conquest. What Sumner is repeatedly battling to resist is the beguiling moral irresponsibility of being indifferent to evil and others' pain. His eventual decision to defy Drax's and Baxter's moral relativism and actively oppose their wickedness is thus an ultimately altruistic act committed for the sake of the other, though unspecified by a concrete face. 
What also connects Conrad's and McGuire's novels is that they show the devastating impact pure evil, one's long-term exposure and submitting to the most egoist and brutish desires and urges, can have on a person's psyche: Kurtz descends into paranoid insanity and Drax's bottomless lust grows into ungovernable alcoholism. However, neither of them offers moral resolution in the form of a universalizing judgement or hopeful vision as they both conclude with the metaphorical image of darkness. While Marlow and his audience on the ship watch the sea flow "into the heart of immense darkness" (Conrad, 1983, p. 121), Sumner is looking into the eyes of a polar bear at the Berlin Zoo:

It sniffs the air and stares at him, its gimlet eyes like strait gates to a larger darkness. Sumner would like to look away, but can't. The bear's gaze holds him tight. [...] He feels a moment of fear and then, in its wake, as the fear fades and loses its force, an unexpected stab of loneliness and need. (McGuire, 2016, p. 326)

Sumner comes to understand that his moral victory was by no means final and that the darkness of the bear's fearful otherness is only indicative of the enigmatic and ominous depths of his own soul. The story thus ends with the protagonist's realization that one's ethical being requires unceasing and strenuous efforts of restraint and self-denial, one whose immediate rewards are uncertain as living selflessly for others without being reciprocated may result in frustrating loneliness and isolation.

\section{Conclusion}

The North Water represents a valuable contribution to the maritime canon and manages to incorporate a number of literary inspirations, from $19^{\text {th }}$-century seafaring yarns to Cormac McCarthy's novels, into an original and intriguing story. In terms of its treatment of ethical issues the novel draws strongly on the fiction of Joseph Conrad, reworking some motifs and thematic concerns from Lord Jim and Heart of Darkness. In the vein of the first, McGuire presents a decent but fallible person, morally evasive because of a past failure for which he feels ashamed and the memory of which he is trying to escape, whose eventual acceptance of the fact that what truly gives his life meaning is his relationship with other human beings resonates with Lord Jim's realization that "[y]ou take a different view of your actions when you come to understand, when you are made to understand every day that your existence is necessary - you see, absolutely necessary - to another person" (Conrad, 1999, p. 179). In the vein of the latter, he places his protagonist into extreme circumstances far away from the 
civilized world where he has to rely on himself and on the strength of his character in times of a crisis. However, while in Heart of Darkness the worst atrocities occur ashore in the depth of the immense African wilderness, The North Water is far more claustrophobic in this regard as it concentrates much of its distressing action in the limited space a whaling ship. In this ship, burdened by the fraudulent intentions and dubious motives of some of its crew members and isolated in the harshness of the Arctic north water, McGuire creates a morally defective universe in which the essential norms and rules of civilized behaviour soon become fluid as wicked individuals twist, turn and transgress them as it suits them.

Trapped in such circumstances, Sumner is forced to overcome his bitterness and confront the threat of total moral chaos and anarchy. He needs to revive his inner strength so as to assume responsibility for his own conscience and other people in consequence. The novel recalls Conradian, and Levinasian, ethics of alterity through the personal relation to the other and the requirement to subordinate oneself to the needs and demands of this other, to act altruistically and selflessly even though such behaviour can disturb one's comfort and safety. However, McGuire complicates Sumner's situation by making the other monstrous, an embodiment of utmost evil beyond the range of accepted, and acceptable, social categories, an individual resistant and immune to any attempt of moral contestation. Sumner's encounters with Drax's bestiality demoralize his shaken belief in humanity to such an extent that only thanks to an opposite extremity, when he survives death and experiences spontaneous and unconditional kindness from complete strangers, does he eventually reassess his stance of resigned scepticism. Using the background story of a Victorian whaling expedition endowed with a modern sensibility through the vividness of language and style, The North Water addresses ethical queries which both echo and transcend those of Conrad's classics, and whose timelessness makes them relevant to analogous dilemmas of the present-day world, particularly that of retaining an ethical relationship with the other when confronted with excessive evil and cruelty committed for their own sake and defying all principles of humanity and rational reasoning.

\section{Works cited:}

Andress, D. 1998. "Truth, Ethics and Imagination: Thoughts on the Purpose of History." In: Arnold, J., K. Davies and S. Ditchfield (eds.). History and Heritage: Consuming the Past in Contemporary Culture. Shaftesbury, Dorset: Donhead. 
Arenas, E.C. 2011. "Villains in Our Mind: A Psychological Approach to Literary and Filmic Villainy.” In: Fahraeus, A. and D.Y. Çamoğlu (eds.). Villains and Villainy: Embodiments of Evil in Literature, Popular Culture and Media. Amsterdam and New York: Rodopi, pp. 3-27. Blanchot, M. 1986. "Our Clandestine Companion.” In: Cohen, R.A. (ed.). Face to Face with Levinas. Albany: State University of New York Press.

Cartwright, J. 2017. "The North Water by Ian McGuire review - a shocking evocation." The Guardian, February 5, 2017. [qt. 15-4-2019]. Available at:

$<$ https://www.theguardian.com/books/2017/feb/05/the-north-water-ian-mcguire-review> Chomsky, N. 1988. Language and Problems of Knowledge: The Managua Lectures. Cambridge, Massachusetts: MIT Press.

Conrad, J. 1983 (1899). Heart of Darkness. London: Penguin Books.

Conrad, J. 1999 (1900). Lord Jim. Mineola: Dover Publications.

Dilman, I. 2005. The Self, the Soul and the Psychology of Good and Evil. London and New York: Routledge.

Dunmore, H. 2016. "The North Water by Ian McGuire review - a voyage into the heart of darkness." The Guardian, February 19, 2016. [qt. 15-4-2019]. Available at:

$<$ https://www.theguardian.com/books/2016/feb/19/the-north-water-ian-mcguire-review>

Evans, D. 2016. “Ian McGuire, The North Water: 'Subtle as a harpoon in the head, but totally gripping', boo review." The Independent, February 9, 2016. [qt. 15-4-2019]. Available at: $<$ https://www.independent.co.uk/arts-entertainment/books/reviews/ian-mcguire-the-northwater-subtle-as-a-harpoon-in-the-head-but-totally-gripping-book-review-a6856011.html> Forbes, M. 2017. “The North Water review.” The Financial Times, February 5, 2017. [qt. 264-2019]. Available at:

$<$ https://www.ft.com/content/3d37ccfc-c68c-11e5-b3b1-7b2481276e45>

Gibson, A. 2001. Postmodernity, Ethics and the Novel. London and New York: Routledge.

Guerard, A. 1958. Conrad the Novelist. Cambridge: Harvard University Press.

Historia Editor, 2017. "Historia Interviews: Ian McGuire.” March 11, 2017. [qt. 15-4-2019]. Available at: http://www.historiamag.com/historia-interviews-ian-mcguire/

Hunt, D. "Ian McGuire: Questions \& Answers." Foyles.co.uk. [qt. 3-5-2019]. Available at: $<$ https://www.foyles.co.uk/Ian-McGuire>

Hyde, S. 2017. "Writing as an act of hope: an interview with Ian McGuire." The American Literary Review, February 1, 2017. [qt. 15-4-2019]. Available at: $<$ https://americanliteraryreview.com/2017/01/02/writing-as-an-act-of-hope-an-interviewwith-ian-mcguire/> 
Kohlke, M-L., and C. Gutleben, 2010. "Introduction: Bearing After-Witness to the Nineteenth Century." In: Kohlke, M-L. and C. Gutleben (eds.). Neo-Victorian Tropes of Trauma: The Politics of Bearing After-Witness to Nineteenth-Century Suffering. Amsterdam and New York: Rodopi, pp. 1-34.

Mandler, P. 2002. History and National Life. London: Profile Books.

McGinn, C. 2003. Ethics, Evil and Fiction. Oxford: Oxford University Press.

McGuire, I. 2016. The North Water. London: Scribner.

Mills, J. 2016. "On the brink of extinction.” In: Naso, R.C. and J. Mills (eds.). Ethics of Evil: Psychoanalytic Investigations. London: Karnac, pp. 3-43.

O'Donnell, P. 2016. "The North Water by Ian McGuire review: the elements of style." The Irish Times, February 13, 2016. [qt. 5-4-2019]. Available at:

$<$ https://www.irishtimes.com/culture/books/the-north-water-by-ian-mcguire-review-theelements-of-style-1.2532589>

Onega, S., C. del Río and M. Escudero-Alías, 2017. "Introduction.” In: Onega, S., C. del Río and M. Escudero-Alías (eds.). Traumatic Memory and the Ethical, Political and Transhistorical Functions of Literature. Basingstoke: Palgrave Macmillan, pp. 1-17.

Paulson, R. 2007. Sin and Evil. New Haven: Yale University Press.

Pojman, L.P., 2000. The Moral Life: An Introduction Reader in Ethics and Literature. Oxford: Oxford University Press.

Rigsby, J. 2016. "The North Water: A Blood-Drenched Tale of Arctic Whalers." The Los Angeles Review of Books, May 3, 2016. [qt. 10-4-2019]. Available at:

$<$ https://lareviewofbooks.org/article/the-north-water-a-blood-drenched-tale-of-arcticwhalers/\#!>

RNZ, 2017. “A wild, dark whaling tale.” Rnz.co.nz, March 11, 2017. [qt. 6-5-2019]. Available at: $\quad<$ https://www.rnz.co.nz/national/programmes/saturday/audio/201836266/a-wild-darkwhaling-tale $>$

Russell, B. 1912. The Problems of Philosophy. E-book (www.Abika.com).

Steger, J. 2017. "How Ian McGuire wrote his acclaimed novel of a whaling ship full of dark deeds.” In: The Sunday Morning Herald, February 9, 2017. [qt. 29-5-2019]. Available at: $<$ https://www.smh.com.au/entertainment/books/how-ian-mcguire-wrote-his-acclaimed-novelof-a-whaling-ship-full-of-dark-deeds-20170209-gu98pc.html> Toibin, C. 2016. "The North Water review." The New York Times, April 11, 2016. [qt. 10-42019]. Available at: $<$ https://www.nytimes.com/2016/04/17/books/review/the-north-water-byian-mcguire.html> 
Weil, S. 1968. On Science, Necessity and the Love of God. (Trans. R. Rees). Oxford: Oxford University Press.

\section{Endnotes}

${ }^{1}$ For instance, the opening line of The North Water, "Behold the man", is reminiscent of that of McCarthy's novel, "See the child". Also, some of the traits of the Judge, Blood Meridian's central villain, can be seen in McGuire's Henry Drax.

${ }^{2}$ Interestingly, Marlow mentions the North Pole as one of the destinations of his boyhood seafaring dreams, which he was unable pursue (Conrad, 1983, p. 33), and so Sumner's adventures beyond the Arctic Circle can also be taken as McGuire's response to this "absence" in Conrad's hero's travelling experience.

Petr Chalupský

Department of English Language and Literature

Faculty of Education, Charles University

Magdalény Rettigové 4

11639 Praha 1

Czech Republic

petr.chalupsky@pedf.cuni.cz 